Darja Mertelj

DOI: $10.4312 /$ vestnik.7.313-317

Univerza v Ljubljani

Filozofska fakulteta

Darja.mertelj@ff.uni-lj.si

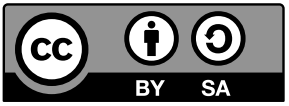

\title{
NUOVO CONTATTO A1 IN NUOVO CONTATTO A2
}

Rosella Bozzone Costa, Monica Piantoni, Chiara Ghezzi (2014) Nuovo contatto: corso di lingua e civiltà italiana per stranieri A1. Torino: Loescher. ISBN 978-88-583-0860-8, $23,10 €$ (pri MK, center Oxford).

Monica Piantoni, Rosella Bozzone Costa, Chiara Ghezzi (2014) Nuovo contatto: corso di lingua e civiltà italiana per stranieri A2. Torino: Loescher. ISBN 978-88-58-30862-2, $27,20 €$ (pri MK, center Oxford).

V letih 2014 in 2015 je na tržišče prišel prenovljeni učbeniški komplet Nuovo Contatto, in sicer za ravni $\boldsymbol{A} \boldsymbol{1}$ in $\boldsymbol{A 2}$, v pripravi za leto $2015-2016$ je še $\boldsymbol{B} 1{ }^{1}$ Založba Loescher doslej na slovenskem tržišču še ni bila stalno prisotna, čeprav so nekateri učitelji poznali predhodni učbeniški komplet Contatto. Sedaj je omenjena učbeniška serija v veliki meri prenovljena s precej elementi predhodnega koncepta, ki so jih nekateri slovenski učitelji italijanščine kot tujega/drugega jezika že cenili.

Učbeniška serija Nuovo Contatto je seveda namenjena širokemu krogu uporabnikov za ves svet, predvsem za mlajše, dinamične osebe, čeprav ne v prvi vrsti gimnazijcem in srednješolcem v srednjem strokovnem izobraževanju. Kljub temu lahko že ob prvih vtisih ugotavljamo, da bo prav tej ciljni skupini pričujoča prenovljena izdaja postala verjetno najbliže. Zakaj? Zaradi tehničnih lastnosti. Z nakupom učbenika pridobi vsakdo kodo, s katero lahko naloži v svojo poljubno tehnično napravo (osebni računalnik, tablica, pametni telefon ipd.) vse osnovne in številne dodatne vsebine učbenika, tj. učbenik v obliki digitalne knjige (ital. libro digitale), vse zvočne zapise, transkripcije slušnih besedil, videoposnetke s pripadajočimi nalogami ipd. Tako učitelj kot učenec torej prek kode dostopata do številnih raznolikih vsebin za kupljeno stopnjo učbenika, ki sicer niso prosto dostopne.

Papirnati del učbenika kot temeljno učno sredstvo torej »ostaja na šolskih klopeh«, vendar z znatnim obsegom digitalne vsebine, ki je v enaki meri dostopna učitelju in

1 Novembra 2015 je v tej seriji izšel še zadnji učbenik, in sicer za raven B1, ki je v decembru $2015 \mathrm{v}$ fazi potrjevanja za višje oz. zadnje letnike italijanščine kot J2 oz. TJ v slovenskem srednjem šolstvu. Učbenik za raven B1 ohranja enako glotodidaktično zasnovo kot celotni niz učbenikov te serije. 
učencu: ta »tehnična « modernost naj postane spodbuda in način, da bodo današnje mlade generacije raje posegale po mobilnih telefonih, tablicah ipd. tudi za učenje italijanščine kot $\mathrm{TJ} / \mathrm{J} 2$.

\section{VIDNE ZNAČILNOSTI PAPIRNATEGA UČBENIKA}

- Na sprednjem notranjem delu platnic je nazoren fizični zemljevid Italije (ter obenem politični zemljevid z mejami dvajsetih regij), ki korektno prikazuje tudi sosednje države.

- Na zadnjem notranjem delu platnic je reklamno besedilo, ki pojasnjuje digitalne in sorodne vsebine, ki so dostopne brezplačno in preko učbeniške kode na www.imparosulweb.eu in www.booktab.it, ki sta v domeni založbe Loescher (Torino, Italija) - tu so na voljo številni dodatni viri za učitelje in za učenca, ki je predvsem prek video vsebin lahko v stiku z živo rabo jezika, ki se ga uči.

- Kombinacija ilustracij, fotografij in besedil v učbeniku deluje uravnoteženo: slikovna oprema ne prevladuje, strani so »zračne«, kljub temu pa bogate z raznolikimi nalogami za učenje jezika. Slikovni deli so v vlogi orodja: dopolnjujejo in usmerjajo pozornost učenca kot podpora razumevanju, pogosto pa so iztočnice za razvijanje produktivnih spretnosti.

- Barvne oznake učnih enot oz. njegovih delov so nevsiljive, z vtisom jasnosti in nazornosti, pri čemer uporabnik najprej opazi vsebino in ne oznak. Nekaj časa bo torej potrebnega za orientacijo v učbenikih in nadaljnjih pribl. 60 straneh (v isti zvezek integriranega) črnobelega delovnega zvezka in slovničnega pregleda.

- Besedila so tipografsko sicer dobro berljiva, vendar je pisava povsod nekoliko manjša, kar ni nujno prijetno za uporabnike papirnate knjige, toda $\mathrm{z}$ uporabo elektronske verzije si je mogoče glede tega tehnično pomagati.

\section{UČBENIK - PAPIRNATI/ELEKTRONSKI}

V vsakem delu je potencialnih učnih enot »samo« pet, deli pa so od nižjih do višjih ravni obsežnejši, kar nekoliko odslikava dejstvo, da napredek od nižje do višje ravni znanja jezika ni linearen. Teme lekcij posamične ravni v celoti razvijajo znanja za označeno raven (glede na SEJO), kar pomeni, da se učitelj ne more in ne sme ukvarjati pri pouku predvsem s slovnico, pač pa delovati tako, kot učbenik narekuje: razvijati vse štiri zmožnosti ob izdatnem urjenju besedišča in slovnice, vendar samo tiste, ki je za doseganje znanja jezika na določeni ravni potrebna.

- Uvajalna prva in druga stran v vsako učno enoto vsebujeta slikovne iztočnice in tudi že krajše naloge za spoznavanje ključnega besedišča. 
- $\quad$ Sledi nekaj strani (4-5) z oznako »per capire«, ki vsebujejo predvsem naloge slušnega razumevanja in obravnavanje različno dolgih slušnih besedil. V tem delu se pojavljajo tudi že sistematični prikazi uporabe jezika v komunikaciji (funkcije) in naloge, ob katerih učenci komunikacijsko »drilajo« oz. posnemajo sporazumevanje v italijanščini. Gre za primerno kratka besedila za uvajanje nove teme in nekoliko daljša za razvijanje zahtevnejšega slušnega in bralnega razumevanja. Jezik je pogovoren in naraven, posnet $\mathrm{v}$ naravnih okoljih, ter funkcijsko primeren za posamično raven, učenci se postopoma privadijo, da lahko ob prvem poslušanju razumejo le bistvo ali nekaj ključnih informacij (na vsaki ravni zahtevnosti), pri nadaljnjih poslušanjih pa vedno več.

- Zatem so 2-3 strani namenjene urjenju besedišča, pri čemer se izmenjujejo naloge za spoznavanje nadaljnjega besedišča, ter naloge za utrjevanje »pasivnega« in za urjenje »aktivnega besedišča«, deloma tudi še z nadaljnjimi kratkimi slušnimi in bralnimi besedili.

- Sledijo 3-4 strani za slovnico, kjer ponovno lahko opazimo, kako so avtorji dosledno povezovali slovnične strukture z njihovo uporabo v komunikaciji, ter razvijali tako senzibilnost za zaznavanje struktur, kot tudi učenčevo slovnično pravilnost in komunikacijsko tekočnost pri uporabi jezika; tudi v tem delu se pojavljajo slušna besedila.

- Po slovnici v vsaki lekciji sledi stran za izgovor in intonacijo, kar bodo slovenski učitelji najverjetneje izpuščali, saj slovenski učenci praviloma nimajo težav z izgovorom, vsekakor pa je smiselno uporabiti naloge ob slušnih posnetkih, ki navajajo učenca na pravilno intonacijo, ki je tudi za slovenske učence trši oreh, obenem pa se s tem utrjuje sporazumevalne vzorce.

- Sledita 1-2 strani spodbud za ustno in pisno sporazumevanje, kar deluje sicer malo, vendar gre za smiselne naloge (številne igre vlog) in pisanje krajših besedil (glede na zahteve SEJO za ravni A1 in A2), vsekakor pa je potrebno v ta namen dosledno izvajati interaktivne komunikacijske naloge tudi v predhodnih razdelkih lekcije.

- Vsako lekcijo zaključujejo: a) preglednica uporabnih fraz, b) dvostranski »dosje kultura « (korektno poimenovan, saj ne gre za "medkulturnost") in dvostranski test vse snovi lekcije, razdeljen na preverjanje treh sklopov: a) besedišča, b) slovnice in c) funkcij. V teh testih ni slušnega in bralnega razumevanja, saj sta ti dve receptivni zmožnosti obilno urjeni v predhodnih delih učne enote, vključno z »dosje kultura«. Poleg tega vemo, da aktivno (produktivno) znanje jezika predpostavlja znatno raven razumevanja.

Besedila se zdijo v učbeniku za raven A2 morda mestoma precej dolga ali zelo zgoščena, vendar se učitelji zavedajo, da mora nastati pomembna razlika med receptivnim in produktivnim znanjem jezika in da morajo učenci po zaključku ravni A1 in A2 razumeti dokaj dolga, pa tudi tipološko raznolika besedila. 


\section{DEL Z VAJAMI (ITAL. ESERCIZIARIO)}

Nahaja se v zadnji tretjini zvezka in obsega po pribl. 8 strani oz. po pribl. 25 nalog za vsako učno enoto. Naloge so namenjene za domače delo učenca in so urejene glede na razvijanje zmožnosti od receptivnih (slušno in bralno razumevanje) prek nalog za urjenje besedišča in slovničnih struktur do urjenja sporazumevalnih funkcij (razumevanje in aktivno zapisovanje celotnih govornih dejanj). Izpostaviti je potrebno, da morajo učenci tudi za domačo nalogo vsakič opraviti številne naloge bralnega in slušnega razumevanja (število zvočnih zapisov za šolski in domači del učbenika je pribl. 90, od tega tretjina za domače delo), kar nedvomno lahko doprinese k močnemu utrjevanju usvojene italijanščine. Pomemben vidik teh domačih nalog je namenjen prav samostojnemu dodatnemu razvijanju obeh receptivnih zmožnosti, ki so izhodišče za jezikovni vnos, ta pa se predpostavlja za aktivno (produktivno) znanje jezika. Poleg tega je tudi v Delu z vajami zadnja stran pri vsaki enoti namenjena domačemu urjenju izgovora in predvsem intonacije daljših izrazov iz učne enote.

\section{Zgoščenke (z zvočnimi in/ali video zapisi) ni na voljo kot priloge $k$ učbeniku, pač pa si slušna besedila uporabnik (učitelj in učenec) naložita prek kode na sebi najustreznej- ši tehnični medij.}

Zvočna besedila (87 zapisov, od tega pribl. 30 kot del domačih nalog) se slišijo, kot že uvodoma omejeno, kot resnično naravna, saj govorci uporabljajo tudi dialekt, med njimi so tudi tujci, v ozadju so prisotni šumi ali drugi zvoki, nekateri govorijo tudi momljajoče, hlastno, (pre)hitro ipd., kar približuje učbenik realni rabi jezika v Italiji in jih s tem pripravlja na test znanja na ustrezni ravni, po zaključku učenja s posamičnim učbenikom. Podobno velja za video posnetke, ki so dostopni na internih spletnih straneh.

\section{Tudi priročnik za učitelja $\mathrm{z}$ dodatnimi gradivi in testi ni na voljo $\mathrm{v}$ obliki papirnate publikacije, pač pa ga učitelj bere in/ali si ga naloži prek kode na sebi najustreznej- ši tehnični medij.}

Doslej navedene lastnosti tega učbenika lahko znatno »glotodidaktično razbremenijo《 učitelja, saj mu nudijo podporo na različnih področjih oz. pri ciljih, ki jih na področju učenja in poučevanje tujih jezikov sooblikujejo načela Skupnega evropskega jezikovnega okvira in učni načrti za italijanščino kot tuji jezik v RS (za srednješolsko izobraževanje), ter poučevanje/učenje današnjih generacij učencev, ki jim je »preklapljanje« med uporabo spletnih strani (tudi npr. prek pametnih telefonov ipd.) in poukom nekaj samoumevnega.

Ker je učbeniška serija Nuovo Contatto izrazito komunikacijsko zasnovana - morda najbolj dosledno in sistematično med učbeniki, ki so zadnjih nekaj let prisotni na tržišču morda res ni več potrebno izpostaviti, da niso slovnične strukture tiste, ki določajo zaporedje, zasnovo in/ali dinamiko učnih enot, pač pa sporazumevalne vsebine, povezane s funkcijami jezika. To pomeni, da tudi ta učbeniški komplet kljub izdatno prisotnim in odlično 
integriranim razdelkom za urjenje slovnične pravilnosti, sam po sebi ne more in ne sme služiti kot neke vrste »pedagoška slovnica«, in torej splošni slovnični pregled ob koncu »Dela z vajami«, to vlogo predstavlja zgolj v primerni »miniaturi«.

Pomembna odlika tega učbeniškega kompleta je, da je delež nalog, ob katerih učenci urijo uporabo sporazumevalnih vzorcev in jezikovnih struktur za razvoj ustnega in pisnega sporazumevanja/sporočanja, resnično dokaj visok. Če bo učitelj uporabljal ali za domačo nalogo dajal tudi video in ostale vsebine, ki jih nudi dostop preko kode, lahko rečemo, da bo proces učenja italijanščine kot J2/TJ ob tem učbeniku postal „multimedijski““.

Verjetno bo serija Nuovo Contatto našla privržence celo med tistimi učitelji, ki menijo, da lahko predvsem razvijanje čvrstega slovničnega znanja daje učencu najtrdnejšo oporo za znanje tujega/drugega jezika, saj je slovnice v izobilju, vendar naj poudarimo, da so naloge za njeno urjenje preudarno zasnovane in umeščene v celoten proces. V starostnem obdobju 15-19 let je razvojno primerno, da učenci razvijajo tudi »znanje o jeziku« in si z zakonitostmi pomagajo: $\mathrm{v}$ ta namen ta didaktični komplet povsem primerno izpolnjuje zahteve, vendar se priporoča, da učitelj nekatere strukture poglablja tako, da jih primerja s slovenščino/angleščino in s tem utrjuje zavest o jeziku/-ih.

Ker gre za učbeniški komplet, ki ni nastal zgolj za potrebe slovenskih učencev, se razume, da ne more vsebovati poudarka na jezikovnih (morfosintaktičnih) vsebinah, ki so za slovenske učence iz različnih razlogov lahko še posebej težavne - nujno je, da tu nastopi učitelj, ki učencem pomaga s posebej pripravljenimi gradivi za te vidike.

Če primerjamo učbenika za ravni A1 in A2 zlahka opazimo, da so v drugem besedila številnejša in daljša, tudi besedišče in slovnica se uvajata, urita in utrjujeta v kontekstu primerno dolgih in vsebinsko zanimivih besedilih, tako v ,šolskem' kot ,domačem“ delu učbenika, kar je nedvomno velik »komunikacijski« korak za učbenike, ki nastajajo v Italiji. Seveda taka zasnova postavlja učitelja pred velik izziv, da po potrebi pretrese svoje dosedanje koncepte poučevanja: uporablja zamisli, ki izhajajo iz zasnove ,flipped-learning', npr. da učenci pri domačem delu veliko sami delajo na receptivnih zmožnostih, kontekstualiziranem besedišču in slovnici, ter se zatem pri pouku dinamično deluje predvsem na razvijanju produktivnih zmožnosti. 